\title{
Triple Tool Effect: Professional Portfolios in Teaching Foreign Languages*
}

MoJCA JURIŠEVIČ

Faculty of Education University of Ljubljana, Slovenia

JANET ENEVER

Umeå University, Sweden

KARMEN PIŽORN

Faculty of Education University of Ljubljana, Slovenia

Received: 11 April 2012 / Accepted: 2 October 2012

ISSN: 1697-7467

\begin{abstract}
Empirical evidence reveals that portfolios show promise as a tool for stimulating teacher's reflection and professional development. However, very few Slovene teachers have any experience in using this valuable instrument for teaching purposes. In response to this weakness in the system, the teacher's portfolio was included in a national research study investigating the best possible way(s) of introducing foreign languages in the first cycle of the primary school. The main goals of using the teacher's portfolio were: (1) to actively monitor the implementation of the foreign languages, (2) to develop an appropriate foreign language teaching approach through critical professional reflection, and (3) to evaluate the teaching process. The research results confirm the triple tool effect of the portfolio whereby the teachers were able to recognise its value. However, they also perceived some difficulties in the portfolio management process, such as the lack of use of their own learning strategies and superficial understanding of self-regulation. This finding underlines the importance of extensive teacher preparation prior to the use of teacher portfolios in future.
\end{abstract}

Keywords: A teacher's portfolio, implementation of foreign languages, professional reflection, authentic assessment

\section{Herramientas de triple efecto: Portfolios profesionales en la enseñanza de lenguas extranjeras}

RESUMEN: La evidencia empírica revela que el portfolio es una herramienta prometedora para estimular la reflexión del profesor y el desarrollo profesional. Sin embargo, muy pocos profesores eslovenos tienen experiencia en el uso de este valioso instrumento para la enseñanza. En respuesta a esta debilidad del sistema, el portfolio del profesor fue incluido en un estudio nacional para investigar la(s) mejor(es) manera(s) posible(s) de introducir lenguas extranjeras en el primer ciclo de la escuela primaria.

Los objetivos principales de uso del portfolio del profesor han sido: (1) monitorizar activamente la implementación de lenguas extranjeras, (2) desarrollar un enfoque adecuado de la enseñanza de una lengua extranjera mediante la reflexión crítica profesional, y (3) evaluar el proceso de enseñanza. Los resultados de la investigación han confirmado el efecto de triple

\footnotetext{
* This research was supported by Ministry of Education, Science, Culture and Sport of the Republic of Slovenia. The Slovenian National Educational Institute and The European Social Funds.
} 


\begin{abstract}
herramienta del portfolio, mediante la cual los profesores han sido capaces de reconocer su valor. Sin embargo, también han percibido algunas dificultades en su proceso de gestión, tales como la falta de uso de sus propias estrategias de aprendizaje y la comprensión superficial de la autorregulación. Esta constatación subraya la importancia de la preparación extensiva de los maestros antes de empezar a usar el portfolio del profesor en el futuro.

Palabras clave: portfolio del profesor, implementación de las lenguas extranjeras, reflexión profesional, evaluación auténtica.
\end{abstract}

\title{
1. INTRODUCTION
}

The starting age of learning the first foreign language in Slovenia in state schoolsis nine years (Year 4)which is relatively late in Europe. In response to both EU language policy recommendations and to parental pressure, the Ministry of Education, Science, Culture and Sport of the Republic of Slovenia decided to lower the starting age to age 6 by first setting up a project group of university researchers, teacher trainers, foreign language and primary teachers who would pave the path for the legalisation of foreign languages. The goal of the two-year project Implementing Foreign Languages to the First Triad of Primary School (from now on IFLFTPS project) was firstly to investigate the current provision for teaching foreign languages in the first triad of the primary school (6-8 years)(PevecSemec et al, 2009). A base line study was a priority for establishing the current position, as $65 \%$ of primary schools had been offering some kind of foreign language provision since 2007 for this age group (Kač, 2007). Secondly, the project aimed to investigate which teaching methods might be most suitable to the children of six to eight years of age.

In this context, we aimed to explore whether the foreign language teacher portfolio contributed to the quality of the foreign language implementation process. The teacher portfolio objectives were: (1) to actively monitor the implementation of the foreign language, (2) to develop an appropriate foreign language teaching approach through critical professional reflection, and (3) to evaluate the teaching process. In other words, the foreign language teacher portfolio had two main roles (Juriševič, 2008a, 2008b): (1) procedural, in order to develop the teachers' reflection, encourage their professional development and their selfconcept, as well as improve the quality of learning and teaching (Berilland Whalen, 2007; Juriševič, 2006; Juriševičet al., 2004; Loughranand Corrigan, 1995; Sentočnik, 1999; Wade and Yarbrough, 1996) and (2) evaluative, thus being a tool for teachers to present their pedagogical competences and knowledge of the new professional experiences related to the project goals (Campbell et al., 2000; Darling-Hammond and Snyder, 2000; Juriševič, 2006; Lyons, 1998; Meyer andTusin, 1999; Porteret al., 2001; Zeichner\& Wray, 2001).

In this article we will discuss the three main goals of managing the teacher portfolio and show how this instrument may be used as a triple tool in exploring teachers' implementation development of teaching approaches in which teachers are both subjects and objects of their own professional reflection.

\section{A teachers' PORTfolio}

A teachers' portfolio is generally conceptualized as a set of meaningful content points or artefacts. It normally contains selected evidence of performances and/or examples of work and 
is accompanied by teachers' entries, such as reflections, their own products and other similar evidence (Seldin, 1991; Wolf and Dietz 1998; Smith andVan Der Westhuizen, 2000).

Portfolios have been found to show promise as a tool for teacher evaluation and professional growth (Wolf, 1996; Beers et al., 2000; Bond et al., 2000; Tucker et al., 2002; Attinelloet al., 2006) and especially as a tool for promoting reflective practice (Adams, 1995; Wade andYarlborough, 1996; Woodward, 1998; Klenowski, 2002; Conderman, 2003). They are quite widespread in pre-service teacher training (Cerbin, 1993; Conderman, 2003; Pecheone and Chung, 2006), less so within in-service frameworks and even less likely to be found as a tool for implementing educational innovations. However, recent studies by Smith and Van Der Westhuizen (2000), Brady (2001), and Dinham and Scott (2003) indicate the success of the use of portfolios by in-service teachers as part of their continuing professional development. In this context, reflective practice can be seen to be a critical tool for analysing and evaluating actions undertaken in the professional setting (Black, 2002).

In the literature, a number of outstanding benefits for a teacher using a professional portfolio as a learning tool have been emphasised, such as raising awareness of subjective theories, developing professional reflection and critical thinking in relation to oneself and to pedagogical practice, learning on higher thinking levels which includes understanding, researching and solving problems and forming creative syntheses etc. (Campbell et al., 1997; Darling, 2001; Darling-Hammond and Snyder, 2000; Hauge, 2006; MansvelderLongayroux et al., 2007; Reynolds, 2000; Wade and Yarbrough, 1996; Zeichnerand Wray, 2001). In addition to the functions described above a portfolio may perform other roles. It offers an important authentic instrument for evaluating personal goals of innovations and projects. This function gives the portfolio a qualifying purpose which has previously been emphasised more often in relation to employment issues (Reynolds, 2000). In addition, a portfolio offers has a documentary function which in the processes of project evaluation and innovation seems to be very useful.

Finally, some research studies have shown that a portfolio may have a strong impact on teaching. Zeichner and Wray (2001) report that those teachers who have previously had personal experience of using a professional portfolio use a wider range of different assessment tools and have more detailed notes on their students' learning development.

Thus, the role of a portfolio in the context of foreign language learning and teaching can be seen as being of vital importance as it meets numerous foreign language teachers' needs (Bernhardt and Hammadou, 1987; Day and Shapson, 1996; Fox, 1999; Moore, 1996). Foreign language teachers often teach language through particular content or content areas whereby teachers' language competences and content knowledge interrelate (Bernhardt and Hammadou, 1987; Fox, 1999). The research has also indicated that foreign language teachers perceive themselves as lonelier and identify themselves as having little contact with other teachers (Davis and Osborn, 2003). Therefore, the portfolio is an instrument which may help to reduce burn out in the early teaching career. With this critical aspect in mind, it seems valuable to introduce pedagogical undergraduate linguistic study programmes so that future teachers are able to develop and use strategies for professional development and to limit isolation (Day and Shapson, 1996; Fox, 1999). 


\subsection{Managing a portfolio}

Keeping the portfolio is not too demanding a task overall (Campbell et al., 1997), however, it does require the teacher to insert entries in real time, to be consistent in storage, organization and writing reflections and to have good time management skills (Babin et al., 2002). Using deep learning strategies, as opposed to surface learning, requires more personal commitment, mental energy and time.

Managing a portfolio usually has three steps (Campbell et al., 1997; Seldin, 1991): Firstly, the teacher selects relevant content, and then chooses the content that is the most authentic representation of a certain process or goal (achievement, product, competence). In the third step, s/he reflects and/or comments on the selected content, which means, that $\mathrm{s} / \mathrm{he}$ evaluates the impact of the learning and teaching practice on her/his own professional development and/or certain innovations or projects.

\subsection{The Importance of professional reflection in keeping a portfolio}

Reflection is understood as "a mental process (re)structuring teaching experience, problem or the existing knowledge" (Korthagen, 2001: 58), which is reflected in a revised (improved) professional teaching approach.

Reflection and implementation of innovations and improvements in teaching practices are closely related since teachers learn from their practical teaching experiences. In this process reflective learning is a key factor (Hatton and Smith, 1995). This learning is characterised by teachers critically evaluating an experience after its in-depth reflection (either individually or in social interaction), and then building or developing with the new acquired knowledge their practical (professional) knowledge and/or (re)designing the (existing) mental structures.

In the context discussed here, the role of the portfolio is twofold. On the one hand, the level of teachers' reflective learning is shown in the content points which a teacher presents in the portfolio with the aim of demonstrating her/his teaching competences, and on the other, portfolio management itself which requires the use of different metacognitive strategies.

A portfolio, therefore, combines the stimulation to two different types of reflection (Schon, 1987), namely (1) the reflection of pedagogical activities in the form of certain products, when the teacher considers her/his experienced pedagogical moments in the foreign language classroom from different perspectives (e.g. storytelling, poster design, a TPR activity), and (2) the reflection during the portfolio management, when the teacher is preparing and designing its individual components (e.g. monitoring and adapting the content points to the objectives of the project).

\subsection{The impact of pedagogical context on managing a portfolio}

An importantfurther condition in designing a relevant portfolio in addition to factors such as creativity, authenticity, and representativeness is the teaching (working) environment within which the teacher creates her/his portfolio. A number of researchers (Breault, 2004; Darling, 2001; Loughran and Corrigan, 1995; Meyer and Tusin, 1999; Shulman, 1998; Quinlan, 2002; Wade and Yarbrough, 1996) stress the importance of a collaborative climate and effective interpersonal communication at various stages of portfolio formation, proposing that this is 
more likely to enable the teacher to acquire the necessary information for portfolio design, to receive the feedback on her/his work, to ask/receive advice and help.

\section{THE METHOD}

\subsection{The participants}

24 qualified primary teachers specialised in teaching English (20) and German (4) participated in the study. Their average age was 37 years. They were part of the project group for implementing foreign languages to the first triad of the primary school in 2008/2009 school year. 12 participating teachers taught in rural schools and 12 in urban schools. They had 10 years of teaching experience on average. Most of the teachers (16) taught the foreign language as extra lessons, and 4 combined language learning with other curriculum areas.

\subsection{Description of the teacher portfolio}

In developing their portfolio system, the experts responsible for the relevant outcomes of the IFLFTPS project were intent that a teacher's portfolio should not be a scrapbook filled only with colourful images and catchy captions (Tucker et al., 2002; Beers et al., 2003). Hence, guidelines were developed to clarify the requirements under which teachers developed and maintained portfolios.

For the purpose of the IFLFTPS project the following portfolio components were presented to the teachers to include in their portfolios:

- A Cover Page with basic information of the portfolio content and the portfolio author (name, e-mail, telephone, education, job and school).

- Portfolio Guide has two parts: the Author's Contribution and the Table of Contents. The former gives an overview of the portfolio content (a brief account of the portfolio design goals, the main findings and the teaching goals), the latter shows the organisational and content structure of the portfolio which is open.

- The Professional Biography and The Participatory Motivation to get involved in the project (motivation and training for teaching foreign languages, number of teaching years, number of years of teaching a foreign language, class description (number of students, gender, school performance, foreign language experience, etc.), brief description of foreign language lessons including assessment, homework assignments and materials resources.

- Implementation monitoring: observation/monitoring forms and documentation materials, such as transcriptions, photos and children's products which best represent the implementation of the foreign languages to the selected groups; one sample lesson plan).

- The primary areas: listening and reading comprehension, oral interaction, written production, language awareness, intercultural awareness, pupils' learningself-esteem: each area had to be presented with at least one example giving the teacher the opportunity to show the quality of her/his teaching (procedural, monitoring, evaluative). 
- Self-selected Components represent the content (one or more points) which is specified as mandatory only in terms of presence. The teacher may include any other content points which provide additional evidence of her/his competence in introducing foreign languages.

- Evaluation of the teaching process and the way forward is the final component of the portfolio. Here the teacher critically evaluates the methodology (methods) of introducing foreign languages to different age groups, consistent with the objectives of the project. The teacher should highlight the different perspectives of various stakeholders involved in the project (students, teachers, parents, school, and society) and consider the advantages and potential shortcomings and pitfalls of introducing foreign languages in the first triad of the primary school, set targets and/or make suggestions for future teaching.

\subsection{The processof managing the portfolio}

Given the importance of the factors discussed in 2.3, it was considered important that a special training should be organized for the participating teachers before the new school year began. They went through a three-phase training: (1) the introductory phase whereby the teachers were confronted with the main aims, the functions, the structure, and the contents of the portfolio, (2) formative assessment phase whereby the participants were monitored and supported by the on-line feedback information and (3) evaluative phase whereby the teachers self-reflected their own teaching practice, their in-depth learning strategies and the value of the use of the teacher's portfolio in the context of the IFLFTPS project.

\subsection{The instruments}

Following the final portfolio submission, a project meeting was organised during which the teachers received group and individual feedback (Juriševič, 2009a, 2009b; Pižorn \& Dagarin Fojkar, 2009; Jazbec and Dagarin Fojkar, 2009). In order to maximise the learning from the innovative experience of managing a professional portfolio in foreign language teaching, two research questions were posed as part of the follow-up empirical study: (1) What kind of relationship did the teachers develop to the objectives and the content of the portfolio? and (2) Which content points and at what level of professional reflection, did teachers select in the process of portfolio management? To answer these research questions, a survey questionnaire was designed and administered. The survey items reflected specific elements of the research questions. Three items were rated using a 5-point Likert-type scale from 5 (strongly agree) to 1 (strongly disagree), and six were open-ended (See the appendix).

\subsection{Data analysis}

Descriptive statistics were used to summarize the results of the survey questionnaire. Responses were reported as frequencies or means, as appropriate. Open-ended teachers' answers were categorized according to their content. 


\section{RESUltS AND DISCUSSION}

The teachers had to perform two innovations in the IFLFTPS project: firstly, they had to teach a foreign language in the first triad of the primary school and at the same time manage the portfolio about their own teaching. The participating teachers who had managed the portfolio over four months evaluated this experience as generally positive, with an average result of 3.75 on a five-point assessment scale. This may be further interpreted as evidence that the teachers accepted the role of the portfolio being linked to the project objectives, while at the individual level the concept of portfolio was elaborated in terms of one's personal learning and developing one's own professional self-image (Mansvelder-Longayroux et al., 2007; Wenger, 1998), which may clearly be established from their statements on how they themselves define and understand their own portfolio. Below are some examples of such statements.

In my opinion portfolio is [...] the first attempt to create an internal personal communication $[\ldots]$ an honest and critical re-think/review of my own work in early foreign language teaching $[\ldots]$ a form of my teaching, presented through a bright/pictorial (photographic) medium and myself as a teacher [...] a reflection of my work in the real time.

In addition, a tendency of the teachers' understanding of the portfolio as a tool leading to the awareness of their own professional development was noticed. In their answers the teachers claimed that the portfolio management was a useful professional experience due to (1) the opportunity provided for evaluation of your own pedagogical work ( $f=7),(2)$ the stimulation to a professional reflection on certain pedagogical problems $(\mathrm{f}=5),(3)$ the portfolio documentation function which enables the sharing of pedagogical experiences and the impact on professional self-image $(\mathrm{f}=5)$ and $(4)$ the stimulation to self-discipline $(\mathrm{f}=1)$.

The portfolio included eight main goals related to professional teacher development (Burroughs, 2001; Tillemaand Smith, 2007). In Figure 1 teachers' perceptions of their accomplishments are provided. The teachers assessed each individual goal on a four-level scale (totally - mostly - partially - absolutely not); figure 1 shows that on average teachers reached most of the goals (average grades between 3.33 and 2.38). According to the teachers' perceptions, the highest achieved goal was "documenting pedagogical work" $(\mathrm{M}=3.33)$, followed by "encouragement for seeking pedagogical solutions" $(\mathrm{M}=3.17)$ and "awareness of pedagogical work and actions" $(\mathrm{M}=3.12)$, while the lowest accomplished goal perceived by the teachers refers to "documenting learning and students' progression" ( $M=2.38)$. 


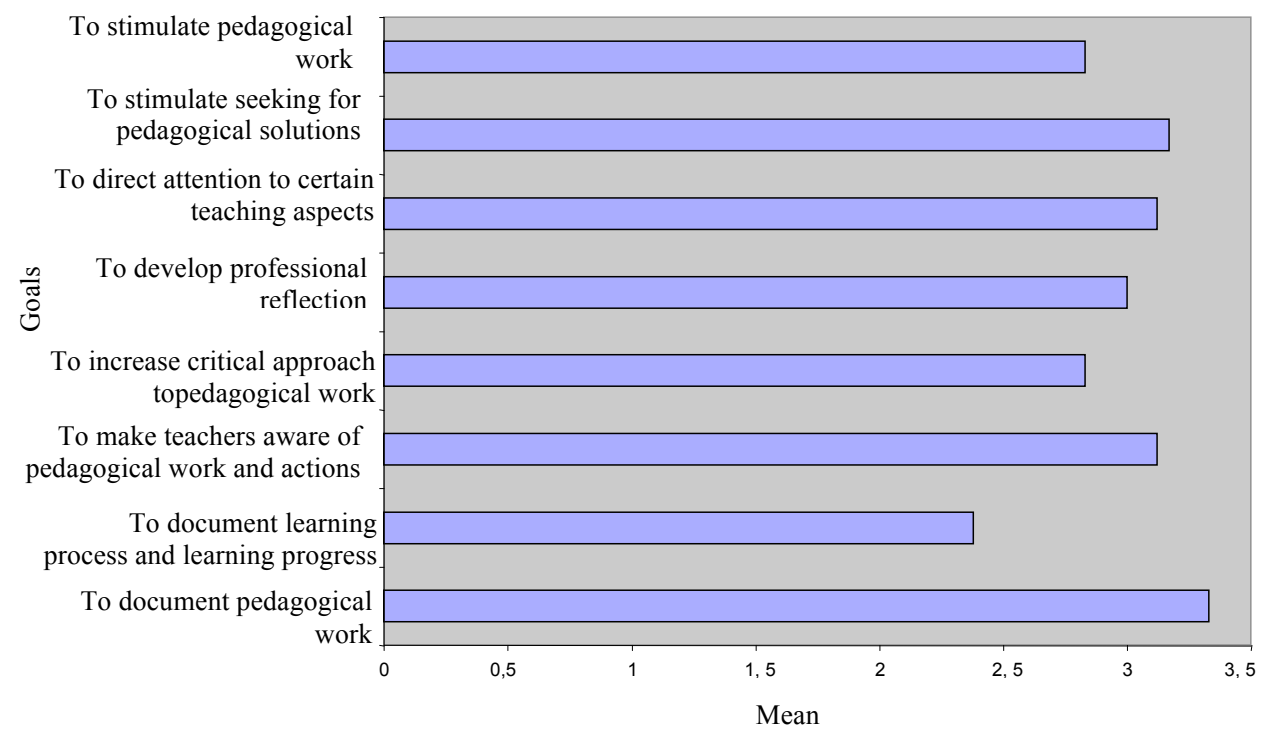

Figure 1. Teachers' perceptions of the accomplished goals in the process of constructing and managing the portfolio

The results presented here indicate that the purpose of the portfolio management was achieved, as the teachers monitored and documented their teaching and were encouraged to express their professional reflection and undergo a creative search for the most relevant pedagogical practices.

It is worth noting at this point of discussion that the lowest goal achieved, already pointed out at the group portfolio analysis (Juriševič, 2009a, 2009b), refers to the fact that teachers in their portfolios did not allocate enough space for reflection on learning and student progress (compare with Berrill and Whalen, 2007 who came to the same conclusion). This finding is thus very important for the further research.

Moreover, the portfolio analysis (Juriševič, 2009a, 2009b) shows that when the teachers were documenting their observations and/or students' products, these were mainly interpreted from their affective perspective, such as a surprise reaction to the children's responses and knowledge, and little or no documentation of the developmental and/or learning theories (i.e. subjective or intuitive teachers' theories instead of professional and knowledge based ones).

The teachers worked on the seven portfolio components related to the project objectives. The main purpose of the components was to encourage and enhance (deepen) their professional reflection in implementing foreign languages into the first triad of the primary school from various perspectives (linguistic, cultural, methodological, pedagogical and psychological), in various forms (observing, monitoring, evaluating, describing, analysing, documenting, commenting), and through a number of attached content points which enabled the teacher to show her/his competences in foreign language teaching.

Figure 2 shows how the teachers assessed professional usefulness of individual components. The "teaching evaluation" $(\mathrm{M}=3.64)$ was assessed as the most professionally useful component 
on the four-level scale, followed by the "monitoring the implementation" $(\mathrm{M}=3.33)$ and the "independently selected components" $(M=3.29)$, while the lowest estimate was given to the components "the author's word/the author's reflection" $(\mathrm{M}=2.88)$ and "motivation for participation in the project" $(\mathrm{M}=3.04)$, and even these two are still positive.

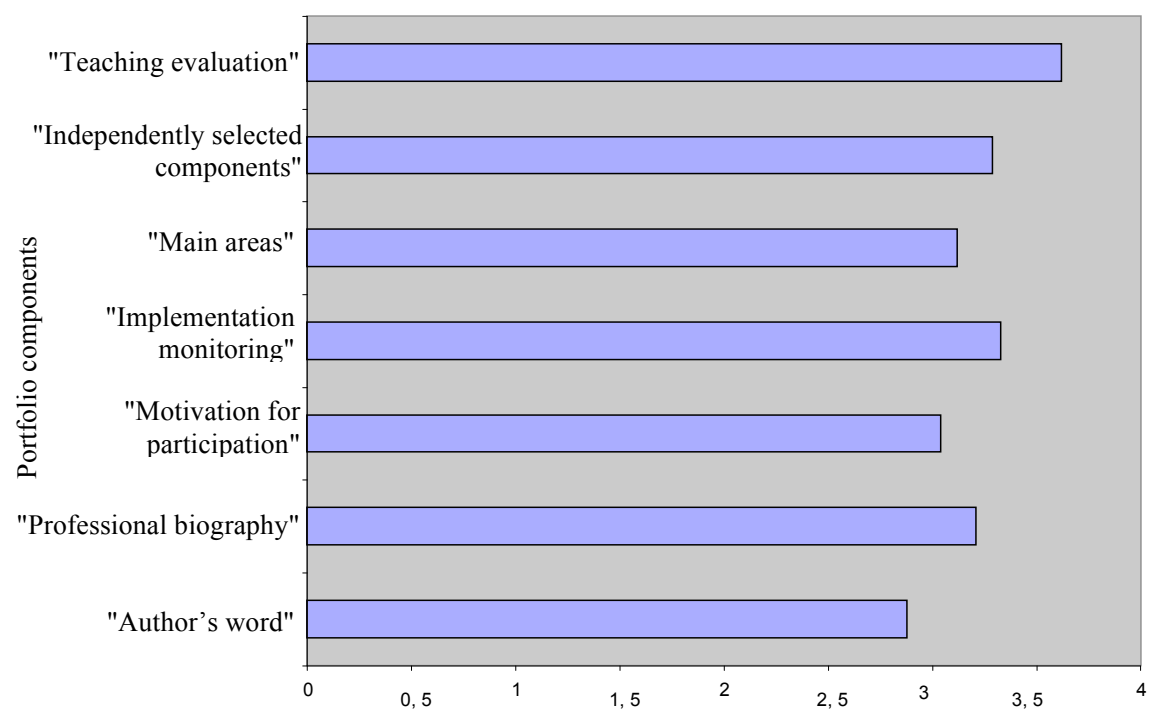

Figure 2: The teachers' estimates of the usefulness of the individual portfolio component management on the four-level scale

Related to the question above the teachers were asked whether they would add any more components to the existing portfolio components. More than half $(\mathrm{N}=14)$ answered that the portfolio already included all the necessary components and therefore they would not add anything more. The remainder proposed the addition of the following: (1) a number of different forms of documenting materials (photographs, audio and videoclips, students' products) ( $\mathrm{f}=6),(2)$ comments from various sources (children, parents, observers, the teacher himself) ( $\mathrm{f}=3)$, (3) additional content points with more details from the main areas $(\mathrm{f}=1)$, (4) teacher characteristics (e.g. learning style) $(f=1),(5)$ suggestions for improvement $(f=1)$, (6) links to curriculum objectives, and (7) electronic content ( $\mathrm{f}=1$ ).

It is particularly interesting to note that when asked to provide suggestions for portfolio improvement some of the teachers mentioned the same content points which had already been included in the list of mandatory content points. It seems that only when the teachers personally experienced the meaning of the proposed content points they were able to reflect on them. One teacher mentioned a new content point, i.e. addition of electronic (ICT) content which may lead to an electronic portfolio which will be a point of interest in the future (Barrett and Garret, 2009; Cohn and Hibbitts, 2004).

Following the teachers' personal experience with portfolio management, the teachers were asked what could be deleted from the portfolio components. 20 teachers (out of 24) 
claimed that they would retain the existing portfolio structure and contents. However, four teachers would omit the following content points from the portfolio: (1) "lesson plans", while keeping the analysis of the conducted lesson, (2) "core/key areas" as they are bound to the learning goals (3) "professional biography", and (4) "motivation for participation". The latter two are more or less constant in teacher portfolios, and represent the initial presentation of the portfolio author (Babin et al., 2002). The teacher's task is to describe her/his professional path and development, to provide her/his professional competences and references, and to present her/his motivation to participate or carry out a specific innovation or a project. On the one hand, the preparation of such content requires time, on the other an ability to analyse one's own motivation for professional work is needed (Seldin, 1991). These results indicate that there was not enough importance given to the last two mentioned content points (professional biography and motivation for participation) during the portfolio management (Juriševič, 2008a, 2008b) which should be improved in the future studies.

Since the majority of teachers in the project were novices in portfolio management, one of the questions in the survey questionnaire referred to the identification of potential difficulties with portfolio management. The assumption proved to be justified, since 22 out of 24 surveyed teachers pointed out certain problems that are commonly recognised in the research literature (Berrill and Addison, 2010). The most frequently mentioned problem was the time required for the organisation and preparation of the portfolio $(\mathrm{f}=12)$. Two teachers raised the issue of the continuation while the content structure was the biggest problem for three teachers. Two more difficulties were identified, i.e. namely the problem of mental effort in selecting the most appropriate content points for the independent selection component $(\mathrm{f}=4)$ and the problem of instruction comprehension for the portfolio management $(\mathrm{f}=4)$.

Finally, at the end of the IFLFTPS project, the teachers were asked to give their expert opinion in the form of additional comments, suggestions and proposals for improving the process of managing the portfolio in the future. Eight teachers responded to this question, highlighting the positive role of the received feedback, the need for more information, examples and discussion during the process of preparing and managing the portfolio, the motivation to continue with portfolio management, the need for time organization improvement and more professional self-confidence to assess and select independently the most authentic content points to be included in the portfolio. These suggestions correspond to the research summarised by Berill and Addison (2010). Both researchers stress the importance of professional support and that teachers understand and feel the portfolio as their own authorship (author's work) and have sufficient technical support. Teachers should understand that portfolio is their own work and that they must take responsibility for its content. The decisionof what to include (and present) in the portfolio, e.g. which competences and (foreign) language skills, should be a gradual and progressive process and should belong more and more to the teacher (Juriševič, 2006, 2007).

All of these concerns, the perceived shortcomings of the teachers and the proposed improvements in the process of portfolio management will have to be examined more closely. According to the results, appropriate strategies to address these issues should be developed in the near future. The teacher portfolio, showing mainly positive effects already in its "pilot" form, should be directed to the following issues: 
- A rethink on the representativeness of certain components and content in the portfolio is needed in order to meet the project's goals. Teachers need to develop their knowledge in the field of developmental psychology, learning and teaching of foreign languages.

- Teachers need to be redirected from paying attention to their own teaching to the learning processes of their students.

- Teachers should be able to become aware of and use flexibly different learning strategies that encourage higher-order skills, metacognition, and motivational orientation for managing the portfolio.

- There is a need for on-going training and on-going guidance to teachers in the process of portfolio management and providing the necessary feedback on selected topics during the process (formative role) and at the end (summative role).

- Exchanges of experiences with the management of portfolios among teachers should be promoted. There should be more opportunities for an open dialogue and wider discussion on the topic of portfolio and for creating a professional climate which simulates professional teacher development thus providing conditions for the development of professional competences and teachers' self-confidence.

The teacher portfolio was introduced in the IFLFTPS project as an instrument for developing a better quality of teaching and for the monitoring of teaching. The research results show that the portfolio, as an instrument for monitoring teaching, played a vital role and had relatively well-performed its function, although, for most of the teachers, this had been their first experience of the preparation of a professional portfolio (Pižorn and Dagarin Fojkar, 2009). From the teachers' answers we may conclude that the management of the portfolio also achieved another goal, i.e. the teachers reported that the portfolio made them monitor and regulate their teaching more consciously, systematically, and thoughtfully (Juriševič, 2009a, 2009b).

The evaluation of the teaching process and the whole project was on-going over a four-month period with a further assessment point at the end of the project. During this time teachers managed the portfolio and prepared specific content. Teachers reported that the evaluation of their teaching using the portfolio was the most useful professional benefit for them. This finding may mean that the moment of evaluation (although being perceived as an equal element in the teaching process or project) is frequently neglected for different reasons and that the portfolio with its specific requirements for self-evaluation serves to stimulate teachers to reflect more extensively on their learning process.

Having identified the benefits of portfolio management for the teachers' professional development and quality language teaching within the IFLFTPS project, we also observed deficiencies and problem areas. First, there are difficulties expressed directly by the teachers which refer to time management, thinking effort and professional self-image. Overall, these responses suggest that these teachers may have used deep learning strategies very modestly and are only moderately active in the process of portfolio management (Wenger, 1998).On the other hand, certain issues were perceived which arise implicitly from the performed evaluation. During the teacher portfolio management the researchers observed that there was a noticeable difference in what the teachers had observed, commented on, tried to explain, or solve. One possible explanation is that the teachers involved in the study may 
well have brought with them a very different prior knowledge of developmental theory and psychology of learning as they had graduated from quite different study programmes (language studies versus primary education programme) which differed in the amount of content dealing with developmental and psychological issues in education. Another issue is that portfolio management is a process which can be acquired only if we gradually gain experience and search for our own way of professional expression (Campbell et al., 1997; Seldin, 1991). Finally, it should be emphasized that the evaluation of portfolio management within the IFLFTPS project clearly indicates that the teachers did care about the quality of the teaching process, however, they should not be left unsupported. We believe that teachers are willing to work, to learn and implement innovations in their work assuming they receive appropriate professional support and are in a community that appreciates and respects their efforts and teaching competence.

\section{REFERENCES}

Adams, T.L. (1995). "A paradigm for portfolio assessment in teacher education.”, in Education, 115,4: 568-570.

Attinello, J.R., Lare, D., and Waters, F. (2006). "The value of teacher portfolios for evaluation and professional growth", in NASSP Bulletin, 90: 132-152.

Babin, L. A., Shaffer, T. R. and Tomas, A. M. (2002). "Teaching portfolios: Uses and development", in Journal of Marketing Education, 24: 35-42.

Barrett, H. C. and Garret, N. (2009). "Online Personal Learning Environments: Structuring Electronic Portfolios for Lifelong and Life Wide Learning", in On the Horizon, 17, 2: 142-152, available from:http://docs.google.com/Doc?id=dd76m5s2_39fsmjdk, accessed 25 March, 2011.

Beers, C., Stronge, J. H., Tucker, P.D., and Gareis, C. (2000). "How effective are portfolios in teacher evaluation?" Paper presented at the Annual Convention of the Association of Supervisionand Curriculum Development. New Orleans, LA, USA, March.

Bernhardt, E. B. and Hammadou, J. A. (1987). “A Decade of Foreign Language Teacher Education", in Modern Languge Journal, 71: 289-299.

Berrill, D. P. and Addison, E. (2010). "Repertoires of practice: Re-framing teaching porfolios", in Teaching and Teacher Education, 30: 1-8.

Berrill, D. P. and Whalen, C. (2007). "Where are the children? Personal integrity and reflective teaching portfolios", in Teaching and Teacher Education, 23: 868-884.

Black, P. (2002). Working inside the black box. Kings College: London.

Board for Professional Teaching Standards: A construct and consequential validity study. Retrieved August 10, 2010, from.http://www.nbpts.org/UserFiles/File/validity_1_-_UNC_ Greebsboro_D_-_Bond.pdf

Bond, L., Smith, T., Baker, W., and Hattie, J. (2000). The Certification System of the National Board for Professional Teaching Standards: A Construct and Consequential Validity Study, Center for Educational Research and Evaluation. Greensboro: University of North Carolina.

Brady, L. (2001). "Portfolios for assessment and reporting in New South Wales primary schools", in Journal of Educational Enquiry, 2, 2: 24-43.

Breault, R. A. (2004). "Dissonant themes in preservice portfolio development", in Teaching and Teacher Education, 20: 847-859. 
Burroughs, R. (2001). "Composing standards and composing teachers: The problem of National Board Certification", in Journal of Teacher Education, 52: 223-232.

Campbell, D. M., Cignetti, P. B., Melenyzer, B. J., Nettles, D. H., and Wyman, R. M. (1997). How to develop a professional portfolio: a manual for teachers. Boston, MA: Allyn and Bacon.

Campbell, D. M., Melenyzer, B. J., Nettles, D.H., and Wyman, R. M. (2000). Portfolio and Performance Assessment in Teacher Education. Boston, MA: Allyn and Bacon.

Cerbin, W. (1993). "Inventing a new genre: the course portfolio at the University of WisconsinLa Crosse", in P. Hutchings (eds.), Making teaching community property: a menu for peer collaboration and peer review. Washington, DC: American Association for Higher Education, 49-56.

Cohn, E. and Hibbitts, B. (2004). "Beyond the Electronic Portfolio: A Lifetime Personal Web Space", in Educause Review 27, 4, available from: http://www.educause.edu/apps/eq/eqm04/ eqm0441.asp?bhcp=1, accessed 25 March, 2011.

Conderman, G. (2003). "Using portfolios in undergraduate special education teacher preparation programs", in Preventing School Failure, 47, 3: 106-111.

Darling, L.F. (2001)."Porfolio as practice: The narratives of emerging teachers", in Teaching and Teacher Education, 17: 107-121.

Darling-Hammond, L. and Snyder, J. (2000). "Authentic assessment of teaching in context", in Teaching and Teacher Education, 16: 523-545.

Davis, J. and Osborn, T. A. (2003). The Language Teacher's Portfolio: A Guide for Professional Development (Contemporary Language Studies). Westport, CA: Praeger.

Day, E. and Shapson, S. (1996). "A national survey: French immersion teachers' preparation and their professional development needs", in The Canadian Modern Language Review, 52: 248-270.

Dinham, S. and Scott, C. (2003). "Benefits to teachers of the professional learning portfolio: A case study", in Teacher Development, 7, 3: 187-202.

Fox, R. (1999). This is who I am: The role of the Professional Development Portfolio in foreign and second language pre-service teacher education. (Doctoral dissertation. George Mason University, Fairfax, VA, 1999). Dissertation Abstracts International, 60-05A, 1516. UMI Microform no. 9933323.

Hatton, N. and Smith, D. (1995). "Reflection in teacher education: Towards a definition and implementation", in Teaching and Teacher Education, 11: 33-49.

Hauge, T. E. (2006). "Porfolios and ICT as means of professional learning in teacher education", in Studies in Educational Evaluation, 32: 23-36.

Jazbec, S. and Dagarin, M. (2010). Zgodnjeučenjetujihjezikov (angleščine, nemščine, francoščine in italijanščine) $\mathrm{z}$ vidikaanalizeopazovanjapouka in portfolievučiteljev. [Early Foreign Language Learning (English, German, French and Italian], in A. Lipavic Oštir (eds.), S. Jazbec (eds.). Pot v večjezičnost-zgodnjeučenjetujihjezikov v 1. VIO osnovne sole [Towards Plurilingualism - Early Foreign Language Learning in the First Triad of the Primary School]. Ljubljana: Zavod RS zašolstvo, 31-56.

Juriševič, M., Polak, A., and Razdevšek-Pučko, C. (2004). "Portfolijo (študentovamapa) kotkonstruktivističnipristop $\mathrm{v}$ profesionalnemrazvojuštudentovrazrednegapouka”. [A portfolio (a student's folder) as a constructivist approach in the professional development of the primary school students], in B. Marentič Požarnik (ed.), Konstruktivizem v šoli in 
izobraževanjeučiteljev [Constructivism in School and Teacher Education]. Ljubljana: Cen terzapedagoškoizobraževanjeFilozofskefakulteteUniverze v Ljubljani, 509-525.

Juriševič, M. (2006). "Portfolio - inštrumentzaspodbujanjestrokovnegarazvojaučiteljev". [Portfolio An Instrument for Stimulating Teachers' Professional Development], in T. Vonta, D. Jurman and T. Zagorski (eds.), Deset let korakov h kakovostnivzgoji in izobraževanjuzavse [Ten Steps to Quality Education for All]. Ljubljana: Pedagoškiinštitut, Razvojno-raziskovalni center pedagoških iniciativ Korakzakorakom, 67-72.

Juriševič, M. (2007). Praktičnopedagoškousposabljanje: vodenjeportfolia (priročnik). [Practical Pedagogical Training: the portfolio management (a handbook)]. Ljubljana: Pedagoška fakulteta.

Juriševič, M. (2008a). Metodologijaspremljanjaučnegaprocesatujegajezika v prvemobdobju OŠ. [The Monitoring Methodology of the Foreign Language Instruction in the First Triad of the Primary School]. Predavanje v sklopuprojektaSporazumevanje v tujihjezikih - Uvajanjetujegajezika in medkulturnega/medjezikovnegauzaveščenja v prvovzgojno-izobraževalnoobdobje v OŠ, $\mathrm{v}$ organizacijiZavodaRepublikeSlovenijezašolstvo.Paper presented as part of the project group training Communication in Foreign Languages - The Implementation of foreign language and intercultural awareness in the first triad of the primary school, organised by the National Education Board]. Ljubljana, Faculty of Education: 25.8. - 29.8. 2008.

Juriševič, M. (2008b). Portfolio - teoretska in strokovnapodlaga. [Portfolios - Theoretical and Professional Foundations], available from: http://zrss.edus.si/moodle/mod/resource/view. php?id=27\&subdir=/Dokumenti/Predstavitve, accessed 25 March 25, 2011.

Juriševič, M. (2009a). Spremljanje in evalviranjepedagoškegadela s portfoliem. [Monitoring and Evaulating Pedagogical Work using a Portfolio]. Predavanje v sklopuprojektaSporazumevanje $\mathrm{v}$ tujihjezikih - Uvajanjetujegajezika in medkulturnega/medjezikovnegauzaveščenja v prvovzgojno-izobraževalnoobdobje v OŠ, v organizacijiZavodaRepublikeSlovenijezašo 1stvo. [Paper presented as part of the project group training Communication in Foreign Languages - The Implementation of foreign language and intercultural awareness in the first triad of the primary school, organised by the National Education Board]. Ljubljana: 13.3.2009.

Juriševič, M. (2009b). Povratneinformacijeučiteljem - analizaportfolievzaučitelje. [Feddback to Teachers - an Analysis of Teachers' Portfolios]. Predavanje v sklopuprojektaSporazumevanje v tujihjezikih - Uvajanjetujegajezika in medkulturnega/medjezikovnegauzaveščenja v prvovzgojno-izobraževalnoobdobje v OŠ, v organizacijiZavodaRepublikeSlovenijezašols tvo.[Paper presented as part of the project group training Communication in Foreign Languages - The Implementation of foreign language and intercultural awareness in the first triad of the primary school, organised by the National Education Board]. ŠmarješkeToplice, Slovenia: 22. - 23.5.2009.

Kač, L. (2007). Pouk tujihjezikov v osnovnihšolah.Poročiloanketneraziskave. [Foreign Language Instruction in Primary School.A questionanire survey]. Ljubljana: Zavod RS zašolstvo.

Klenowski, V. (2002). Developing Portfolios for Learning and Assessment: Processes and Principles. London, New York: Rotledge Falmer.

Korthagen, F. A. J. (2001). "Reflection on reflection", in F. A. J. Korthagen et al. (eds.), Linking Practice and Theory: The Pedagogy of Realistic Teacher Education. Mahwah, NJ: Lawrence Erlbaum, 51-68.

Loughran, J. and Corrigan, D. (1995). "Teaching portfolios: A strategy for developing learning and teaching in preservice education", in Teaching and Teacher Education, 6: 565-577. 
Lyons, N. (1998). "Portfolio possibilities: Validating a new teacher professionalism", in N. Lyons (ed.), With Portfolio in Hand: Validating the New Teacher Professionalism. New York, NY: Teachers College, Columbia University, 11-22.

Mansvelder-Longayroux, D. D., Beiijard, D., and Verloop, N. (2007). "The portfolio as a tool for stimulating reflection by student teachers", in Teaching and Teacher Education, 23: $47-62$.

Meyer, D. and Tusin, L. (1999). "Preservice teachers' perceptions of portfolios: Process versus product", in Journal of Teacher Education, 2: 131-139.

Moore, M. K. (1996). "Challenging the Status Quo of Multicultural Education: For those who cannot wait", in Critical Issues in Teacher Education, 5: 23-45.

Pevec Semec, K., Pižorn, K., Lipavic Oštir, A., Jazbec, S., Brumen, M. (2009). Poskus in postopnouvajanjetujegajezika v prvemvzgojno-izobraževalnemobdobjuosnovnešole. [An Experiment and Gradual Introduction of a Foreign Language into the First Triad of the Primary School], Ljubljana: ZRSŠ.

Pižorn, K. and Dagarin Fojkar, M. (2009). Analizaportfolievzaučitelje. [The Analysis of the Teachers' Portfolios]. Predavanje v sklopuprojektaSporazumevanje v tujihjezikih - Uvajanjetujegajezika in medkulturnega/medjezikovnegauzaveščenja v prvovzgojno-izobraževalnoobdobje v OŠ, $\mathrm{v}$ organizacijiZavodaRepublikeSlovenijezašolstvo.[Paper presented as part of the project group training Communication in Foreign Languages - The Implementation of foreign language and intercultural awareness in the first triad of the primary school, organised by the National Education Board]. ŠmarješkeToplice, Slovenia: 22. - 23.5.2009.

Porter, A., Youngs, P., andOdden, A. (2001). "Advances in teacher assessments and their uses."in V. Richardson (ed.), Handbook of Research on Teaching. Washington, DC: AERA, 259297.

Quinlan, K. M. (2002). "Inside the peer review process: How academics review a colleague's teaching portfolio", inTeaching and Teacher Education, 18: 1035-1049.

Reynolds, N. (2000). Portfolio Teaching: A Guide for Instructors. Boston, MA: Bedford/ St.Martin's.

Schon, D.A. (1987). Educating the Reflective Practitioner: Toward a New Design for Teaching and Learning in the Professions. San Francisco, CA: Jossey-Bass Publishers.

Seldin, P. (1991). The Teaching Portfolio: A Practical Guide to Improved Performance and Promotion/Tenure Decisions. Bolton, MA: Anker.

Sentočnik, S. (1999)."Pomenrefleksijezakakovostnoedukacijo:učiteljev portfolio: instrument zaprocesnospremljanje in vrednotenjeučiteljevegastrokovnega in osebnostnegarazvoja". [The significance of the reflection for a quality education: the teacher portfolio: an instrument for a procedural monitoring and evaluationg of teachers' professional and personal development], in Vzgoja in izobraževanje, 5: 40-43.

Shulman, L. (1998). "Teacher porfolios: A theoretical activity", in N. Lyons (ed.), With Portfolio in Hand: Validating the New Teacher Professionalism (23-38). New York, NY: Teachers College, Columbia University, New York.

Smith, K. and Van der Westhuizen, G. (2000). "Teachers' portfolio reflections: A comparative study", in The Journal of Teacher Development, 4, 3: 339-351

Tillema, H. and Smith, K. (2007). "Porfolio appraisal: in search of criteria", in Teaching and Teacher Education, 23: 442-456.

Tucker, P. D., Stronge, J. H. and Gareis, C. R. (2002). Handbook on Teacher Portfolios for Evaluation and Professional Development. Larchmont, NY: Eye on Education.

Wade, R. and Yarbrough, D. (1996). "Portfolios as a tool for reflective thinking in teacher education?", in Teaching and Teacher Education, 1: 63-79. 
Wenger, E. (1998). Communities of Practice: Learning, Meaning, and Identity. Cambridge: University Press.

Wolf, K. (1996). "Developing an effective teaching portfolio", in Educational Leadership, 63, 6: $34-37$.

Wolf, K. and Dietz, M. (1998). "Teaching portfolios: Purposes and possibilities", in Teacher Education Quarterly, 25, 1: 9-22.

Woodward, H. (1998). "Reflective journals and Portfolios: learning through Assessment", in Assessment \& Evaluation in Higher Education, 23(4): 425-423.

Zeichner, K. and Wray, S. (2001). "The teaching portfolio in US teacher education programs: what we know and what we need to know", in Teaching and Teacher Education, 17: 613-621. 


\section{Appendix}

The survey questionnaire for teachers

Dear Teachers

Please answer the following questions concerning portfolio management.

Thank you for your cooperation.

The research team

1. How do you evaluate your experience of managing the teacher's portfolio within the time of the project? Please, circle most appropriate answer.
a) Very positive
b) Positive
c) Positive and negative
d) Negative
e) Very negative

2. Where do you see the main positive effects of managing the teacher's portfolio?

3. Evaluate the goals of the portfolio management on the four-level scale. How far do you agree with the following statements? Circle most appropriate answer.
a) To stimulate pedagogical work totally - mostly - partially - absolutely not
b) To stimulate seeking for pedagogical solutions totally - mostly - partially - absolutely not
c) To direct attention to certain teaching aspects totally - mostly - partially - absolutely not
d) To develop professional reflection totally - mostly - partially - absolutely not
e) To increase critical approach to pedagogical work totally - mostly - partially - absolutely not
f) To make teachers aware of pedagogical work and actions totally - mostly - partially - absolutely not
g) To document learning process and learning progress totally - mostly - partially - absolutely not
h) To document pedagogical work totally - mostly - partially - absolutely not

4. Evaluate professional usefulness of the teacher's portfolio components on the four-level scale. How far do you agree with the following statements? Circle most appropriate answer.
a) "Teaching evaluation" totally - mostly - partially - absolutely not
b) "Independently selected components " totally - mostly - partially - absolutely not 
c) "Main areas" totally - mostly - partially - absolutely not

d) "Implementation monitoring" totally - mostly - partially - absolutely not

e) "Motivation for participation" totally - mostly - partially - absolutely not

f) "Professional biography" totally - mostly - partially - absolutely not

g) "Author's word" totally - mostly - partially - absolutely not

5. Would you add or/and remove any other components to/from the existing ones in the portfolio in the future?

6. What problems did you encounter in the process of the portfolio management?

7. Please, list any proposals/suggestions/commentaries you can, for future improvement of the portfolio. 